УДК 657.36.422

\title{
МЕХАНІЗМ ФОРМУВАННЯ ФІНАНСОВИХ РЕЗУЛЬТАТІВ У ЗВІТІ ЛІСОГОСПОДАРСЬКИХ ПІДПРИЕМСТВ
}

\section{MECHANISM OF FORMATION OF FINANCIAL RESULTS IN THE REPORT OF FORESTRY ENTERPRISES}

\author{
Кузьменко Наталія Володимирівна \\ магістр, \\ Кременчуцький національний університет імені Михайла Остроградського \\ ORCID: https://orcid.org/0000-0002-7318-9807 \\ Бабіченко Віктор Володимирович \\ доктор економічних наук, доцент, \\ Кременчуцький національний університет імені Михайла Остроградського \\ ORCID: https://orcid.org/0000-0002-3317-6235 \\ циган Раїса Миколаївна \\ старший викладач, \\ Кременчуцький національний університет імені Михайла Остроградського \\ ORCID: https://orcid.org/0000-0001-5955-812X
}

\author{
Kuzmenko Natalia, Babichenko Viktor, Tsyhan Raisa \\ Kremenchuk Mykhailo Ostrohradskyi National University
}

Процеси відображення фрінансових результатів діяльності будь-якого підприємства є важливим етапом обліку, тому з кожним роком вивченню їх багато вчених приділяють все більше уваги. У статті розглянуто важливі питання удосконалення методики фрормування фрінансових результатів на базі лісогосподарських підприємств України. Проаналізовано останні дослідження вітчизняних вчених. Проведений аналіз тлумачення поняття «фрінансового результату» на базі робіт українських науковців та сформовано узагальнююче змістовне визначення, яке охоплює всі особливості та дозволяє отримати повноцінне трактування. Також у роботі розроблено механізм формування фрінансових результатів, який подано у вигляді схеми для зручного та коректного відображення. На основі досліджень було зроблено висновки та представлено пропозиції щодо удосконалення фрормування фрінансової звітності лісогосподарських підприємств.

Ключові слова: облік, лісогосподарські підприємства, система обліку, звітність, фрінансові результати.

Процессы отражения фринансовых результатов деятельности любого предприятия являются важным этапом учета, поэтому с каждым годом изучению их многие ученые уделяют все больше внимания. В статье рассмотрены важные вопросы усовершенствования методики фрормирования фринансовых результатов на базе лесохозяйственных предприятий Украины. Проанализированы последние исследования отечественных ученых. Проведен анализ толкования понятия «финансового результата» на базе работ украинских ученых и сформировано обобщающее содержательное определение, охватывающее все особенности и позволяющее получить полноценную трактовку. Также в работе разработан механизм формирования фринансовых результатов, представленный в виде схемы для удобного и корректного отображения. На основе исследований были сделаны выводы и представлены предложения по усовершенствованию формирования фринансовой отчетности лесохозяйственных предприятий.

Ключевые слова: учет, лесохозяйственные предприятия, система учета, отчетность, фринансовые результаты.

The development of entrepreneurship in the country requires businesses to make the most efficient use of financial resources to achieve maximum effect and realize the mission of the enterprise. Financial and economic results of any enterprise is a key indicator that characterizes the efficiency of its management during the reporting period. The process of reflecting the financial results of any enterprise is an important stage of accounting, so every year many scientists pay more and more attention to these processes. Today, the accounting system has imperfections. Therefore, it is very important to conduct research in this area to obtain a single mechanism developed for each area of activity. Therefore, the authors decided to investigate in depth the economic essence of the criterion of "financial results" on the basis of the works of Ukrainian scientists and formed a generalizing meaningful definition, which covers all features and allows to ob- 
tain a full interpretation. Thus, it was accepted to interpret the financial result as a qualitative indicator of the effectiveness of economic activity, which is defined as the difference between income and expenses for the period, which leads to profit or loss. The latest research of domestic scientists is analyzed. A single mechanism for the formation of financial results of forestry enterprises in the accounting system has been developed. The problem identified is the need to add new analytical accounts to the "operating result" account. After all, the forest industry has its own specifics of work, which requires the delimitation of activities to correctly and fully reflect the indicators in the reporting. therefore, it is proposed to consider the possibility of making adjustments to the statement of financial performance at the state level. Almost all subjects of market relations are interested in obtaining detailed information about the financial condition of the business entity: owners, the state, administrative staff, banking institutions, investors, suppliers, contractors, etc.

Keywords: accounting, forestry enterprises, accounting system, reporting, financial results.

Постановка проблеми. У сучасних умовах питання коректного відображення результатів діяльності у звітності вважається одним з ключових для будь-якого підприємства, не виключенням є лісогосподарських підприємства. Система бухгалтерського обліку в Україні містить суперечності щодо узгодженості фрормування фрінансових результатів у відповідності до видів діяльності. Результативність діяльності відображається у фрінансово-економічних показниках, які більш точно характеризують фінансовий стан суб'єкта господарювання та дають уявлення про економічний потенціал його подальшого розвитку.

Аналіз останніх досліджень і публікацій. Дослідженням тематики визначення фрінансового результату на різних видах підприємства та удосконаленню методики ведення обліку приділяли увагу багато вітчизняних вчених, а саме: Скалюк Р.В. [1], Перчук О.В. [2], Полятикіна Л.І., Новикова С.В. [3], Лагодієнко Н.В. [4], Голячук Н.В. [5], Олійничук О.І. [6] та інші. Так, Скалюк Р.В. [1] у науковому дослідженні прийшов до висновку, величина фрінансового результату $€$ базисом, який забезпечує не тільки життєздатність суб'єкта господарювання, а й відобра- жає рівень результативності, прибутковості господарської діяльності, можливості кількісного зростання основних економічних показників (обсягу виробництва й реалізації, продуктивності праці) та характеризує потенціал стійкого розвитку підприємства, а Полятикіна Л.І., Новикова С.В. [3] зауважили, що аналіз фрінансових результатів не може бути обмежений тільки аналізом чистого грошового потоку або прибутку. Кожен показник дає інсрормацію про підприємство в певному розрізі, і лише комплексний розгляд показників дасть нам можливість отримати повне уявлення про стан підприємства та його подальші можливості.

Наразі залишилися питання щодо методики фрормування фрінансових результатів та відображення їх у звітності підприємства.

Постановка завдання. Дослідити визначення економічної сутності фрінансових результатів та порядку їх фрормування в системі бухгалтерського обліку лісогосподарських підприємств.

Виклад основного матеріалу. Головною метою фрінансової діяльності будь-якого підприємства є отримання фрінансового прибутку, при цьому витрачаючи як найменші затрати. Проте не завжди результатом діяль-

Таблиця 1

Наукові підходи щодо визначення сутності поняття «фрінансовий результат»

\begin{tabular}{|c|l|}
\hline Автори & \multicolumn{1}{|c|}{ Визначення } \\
\hline $\mathbf{1}$ & \multicolumn{1}{|c|}{$\mathbf{2}$} \\
\hline Скалюк Р.В. & $\begin{array}{l}\text { підсумкова категорія результативності господарської діяльності, } \\
\text { котра відображає величину економічних вигод отриманих (втрачених) } \\
\text { підприємством, визначених як різниця між сумами доходів та відповідних } \\
\text { ї витрат, що виражена у абсолютних показникахприбутку (збитку), } \\
\text { які характеризують потенціал прибутковості, економічного зростання } \\
\text { та розвитку підприємства. }\end{array}$ \\
\hline $\begin{array}{l}\text { Полятикіна Л.І., } \\
\text { Новикова С.В. }\end{array}$ & $\begin{array}{l}\text { приріст (чи зменшення) вартості власного капіталу підприємства, що } \\
\text { утвостя в процесі його підприємницької діяльності за звітний період }\end{array}$ \\
\hline Лагодієнко Н.В. & $\begin{array}{l}\text { якісний показник діяльності підприємства, який визначається як різниця між } \\
\text { доходами та витратами і призводить до зростання (прибуток) } \\
\text { або зменшення (збиток) власного капіталу. }\end{array}$ \\
\hline Перчук О.В. & $\begin{array}{l}\text { прибуток, у разі перевищення доходів, отриманих підприємством } \\
\text { за відповідний період внаслідок певної діяльності над витратами, } \\
\text { здійсненими за той же період для забезпечення цієї діяльності, } \\
\text { або збиток -в вротилежному випадку. }\end{array}$ \\
\hline
\end{tabular}


ності може бути отримання прибутку, інколи витрати перевищують суму доходів і підприємство зазнає збитків. Термін «фрінансовий результат» широко використовується на практиці бухгалтерського обліку, проте, його тлумачення у законодавстві України не існує. Багато науковців пропонують своє трактування поняттю «фінансові результати», деякі з них представлено в табл. 1.

Таким чином, категорія «фрінансового результату» вимагає змістовного визначення. Спираючись на розробки вітчизняних науковців запропонуємо загальне тлумачення фрінансового результату. Так, фрінансовий результат - це якісний показник результативності господарської діяльності, який визначається як різниця між доходами та витратами за відповідний період, що призводить до прибутку або ж збитку.

Проблемним питанням $€$ механізм фрормування фрінансового результату, адже залежно від того, для яких цілей він визначається, буде залежати його величина. Відомим $€$ те, що визначення фрінансового результату $\epsilon$ заключним етапом досягнення будь-якої мети. 3 точки зору бухгалтерського обліку, визначенням фрінансового результату завершуються всі звітні періоди.

Сьогодні Звіт про фрінансові результати (Звіт про сукупний дохід) складається з чотирьох розділів:

1) фрінансові результати;

2) сукупний дохід;

3) елементи операційних витрат;

4) розрахунок прибутковості акцій.

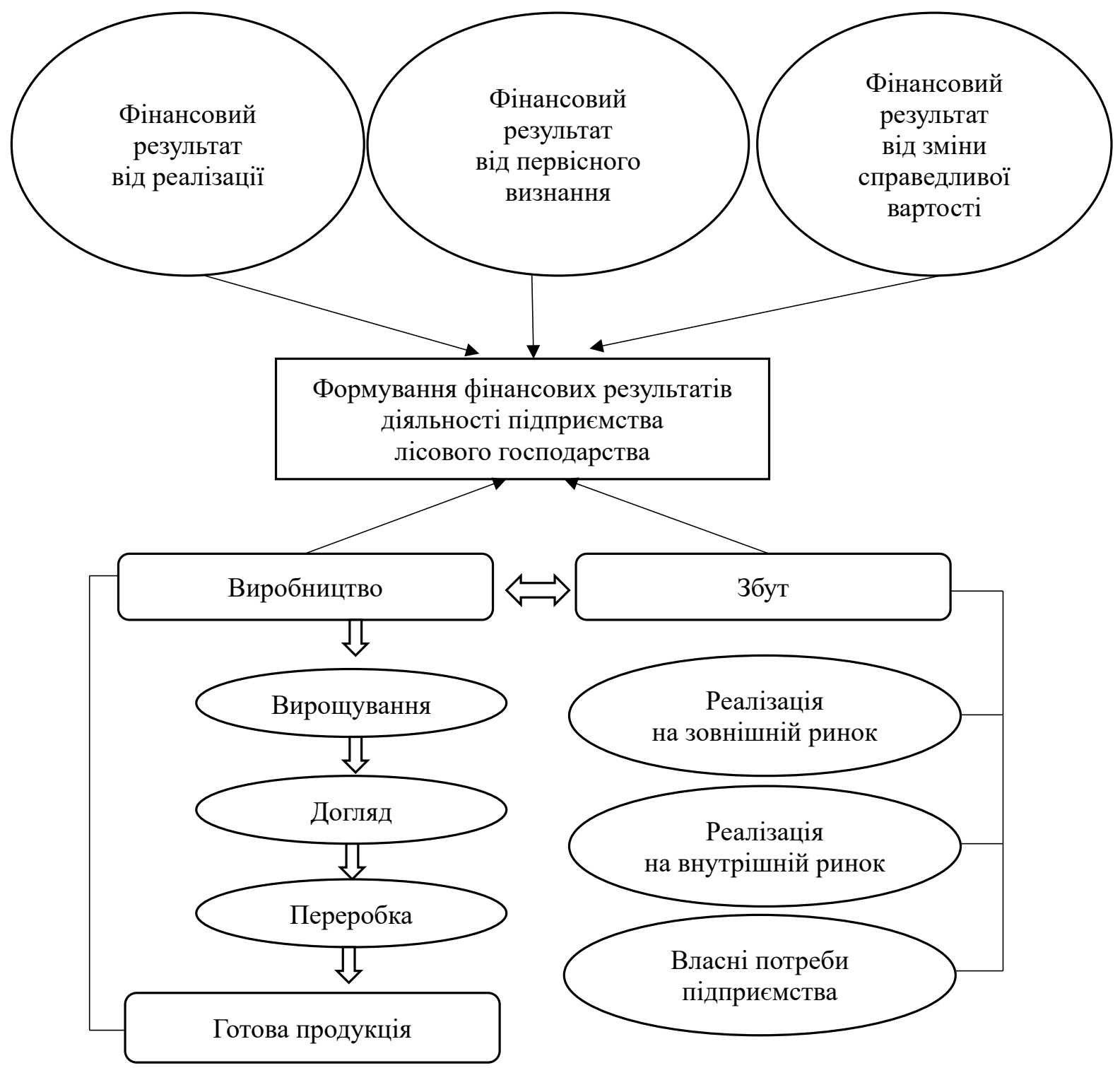

Рис. 1. Механізм формування фінансових результатів на лісогосподарських підприємствах Джерело: розроблено авторами за [2; 5; 6] 
При фрормуванні фрінансових результатів діяльності варто спиратися на специфріку галузі та враховувати всі її особливості. Модель фрормування фрінансових результатів на лісогосподарських підприємствах представлено на рис. 1.

Таким чином, процес фрормування фрінансових результатів $\epsilon$ комплексним механізмом з багатьма елементами. Відповідно до моделі формування фрінансових результатів постає потреба у розмежованому відображенні фрінансових результатів в обліку. Для вирішення поставленого завдання доцільно ввести відповідні аналітичні рахунки до рахунка 791 «Результат операційної діяльності». Кожне підприємство має затверджувати рахунки індивідуально до специфріки роботи підприємства. Для повного та достовірного відображення результатів операційної діяльності підприємств доцільно удосконалити діючу на основі
НП(С)БО 1 форму звітності, а саме, Звіт про фрінансові результати (звіт про сукупний дохід) порядок їх визначення відповідно до викладеної вище пропозиції. Такі зміни будуть доречними не тільки для підприємств лісового господарства, але й для підприємств інших галузей.

Висновки та пропозиції. Отже, категорія «срінансовий результат» $€$ комплексною та вимагає ґрунтовного визначення, яке охоплює всі особливості.

Оскільки лісогосподарські підприємства $€$ специсрічною галуззю виробництва, то з метою отримання оперативної та точної інсрормації про фрінансові результати підприємств потрібно чітко розмежовувати їх за видами діяльності. У свою чергу ці зміни доцільно враховувати у Звіті про орінансові результати, тому варто розглянути можливість внесення змін до змісту діючої форми Звіту про фрінансові результати власне підприємствами на рівні законодавства.

\section{СПИСОК ВИКОРИСТАНИХ ДЖЕРЕЛ:}

1. Скалюк Р.В. Сутність та значення фінансових результатів в системі розвитку господарської діяльності промислових підприємств. Наукові праці Кіровоградського національного технічного університету. Економічні науки. 2010. № 18(1). С. 135-141. URL: http://nbuv.gov.ua/UJRN/Npkntu_e_2010_18\%281\%29_23

2. Перчук О.В. Особливості обліку фрінансових результатів на сільськогосподарських підприємствах. Економічний вісникуніверситету. 2015. № 27(1). C. 57-66. URL: http://nbuv.gov.ua/UJRN/ecvu_2015_27\%281\%29_11

3. Полятикіна Л.І., Новикова С.В. Облік і аналіз фінансових результатів господарської діяльності підприємства. Науковий вісник Ужгородського національного університету. 2018. № 20. URL: http://www.visnyk-econom.uzhnu.uz.ua/archive/20_2_2018ua/38.pdf

4. Лагодієнко Н.В. Облік і контроль фінансових результатів на сільськогосподарських підприємствах. Бізнес-навігатор. 2014. № 1. C. 167-172. URL: http://nbuv.gov.ua/UJRN/bnav_2014_1_34

5. Голячук Н.В. Удосконалення обліку фрінансових результатів діяльності лісогосподарських підприємств. Економічні науки. Серія облік і фрінанси. 2019. № 16. URL: http://oblik-i-finansy.lutsk-ntu.com.ua/index.php/ ekonomichni-nauky-oblik-i-finan/article/view/42/38

6. Олійничук О.І., Витрати, доходи та прибуток у системах обліку й аналізу лісогосподарських підприємств. URL: http://dspace.wunu.edu.ua/bitstream/316497/772/1/dis_\%D0\%9E\%D0\%BB\%D1\%96\%D0\%B9\%D0\%BD\%D 0\%B8\%D1\%87\%D1\%83\%D0\%BA_\%D0\%9E.\%D0\%86..pdf

\section{REFERENCES:}

1. Skaljuk R. (2010) Sutnistj ta znachennja finansovykh rezuljtativ v systemi rozvytku ghospodarsjkoji dijaljnosti promyslovykh pidpryjemstv. Naukovi praci Kirovoghradsjkogho nacionaljnogho tekhnichnogho universytetu. Ekonomichni nauky, 18(1), 135-141. Available at: http://nbuv.gov.ua/UJRN/Npkntu_e_2010_18\%281\%29_23 (in Ukrainian)

2. Perchuk O. (2015) Osoblyvosti obliku finansovykh rezuljtativ na siljsjkoghospodarsjkykh pidpryjemstvakh. Ekonomichnyj visnyk universytetu, 27(1), 57-66. Available at: http://nbuv.gov.ua/UJRN/ecvu_2015_27\%281\%29_11 (in Ukrainian)

3. Poljatykina L., Novykova S. (2018) Oblik i analiz finansovykh rezuljtativ ghospodarsjkoji dijaljnosti pidpryjemstv. Naukovyj visnyk Uzhghorodsjkogho nacionaljnogho universytetu, 20. Available at: http://www.visnyk-econom.uzhnu.uz.ua/ archive/20_2_2018ua/38.pdf (in Ukrainian)

4. Laghodijenko N. (2014) Oblik i kontrolj finansovykh rezuljtativ na siljsjkoghospodarsjkykh pidpryjemstvakh. Biznes-navighator, 1, 167-172. Available at: http://nbuv.gov.ua/UJRN/bnav_2014_1_34 (in Ukrainian)

5. Gholjachuk N. (2019) Udoskonalennja obliku finansovykh rezuljtativ dijaljnosti lisoghospodarsjkykh pidpryjemtsv. Ekonomichni nauky. Serija oblik i finansy, 16. Available at: http://oblik-i-finansy.lutsk-ntu.com.ua/index.php/ ekonomichni-nauky-oblik-i-finan/article/view/42/38 (in Ukrainian)

6. Olijnychuk O. (2011) Vytraty, dokhody ta prybutok u systemakh obliku j analizu lisoghospodarsjkykh pidpryjemstv. Available at: http://dspace.wunu.edu.ua/bitstream/316497/772/1/dis_\%D0\%9E\%D0\%BB\%D1 (in Ukrainian) 